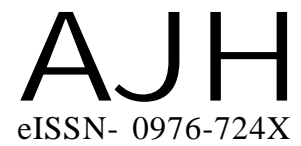

Received : 07.03.2017

Revised : 22.04.2017

Accepted : 07.05.2017
Members of the Research Forum

Associated Authors:

'Department of Horticulture, Faculty of Agriculture, Annamalai

University, ANNAMALAI NAGAR

(T.N.) INDIA

Email : anbumohankarthi2007@ rediffmail.com
Author for correspondence : K. MUTHUMANICKAM

Department of Horticulture, Faculty of Agriculture, Annamalai University,

ANNAMALAI NAGAR (T.N.) INDIA

Email : muthusai121@gmail.com
THEASIAN JOURNALOF HORTICULTURE

Volume 12 | Issue 1 | June, 2017 | 51-54

Visit us -www.researchjournal.co.in

\title{
Yield and yield parameters as influenced by various sources of water soluble fertilizers on chilli hybrid (Capsicum annuum L.)
}

\section{K. MUTHUMANICKAM AND A. ANBURANI ${ }^{1}$}

ABSTRACT : An investigation was conducted to study the effect of water soluble fertilizers on yield parameters of chilli hybrid (Capsicum annuum L.) was carried out during 2015-2016 in the Pudhukuraipettai village at VirudhachalamTaluk in Cuddalore district. Foliar feeding of water soluble fertilizers NPK viz., 19:19:19, 18:18:18, 13:40:13 were given at 0.5 and 1.0 per cent concentration with 5 sprays each starting from 30 DAT at 15 days interval along with 100 and 75 per cent recommended dose of NPK (120:80:80 $\left.\mathrm{kg} \mathrm{ha}^{-1}\right)$, formed thirteen treatments in chilli hybrid. The experimental plots were laid out in Randomized Block Design and replicated thrice. The results obtained showed that 100\% RDF + WSF 1.0\% NPK @ 13:40:13 recorded the highest number fruits per plant, fruit length, fruit girth, fruit weight, yield per plant and yield per hectare.

KEY WORDS : Chilli, Inorganic fertilizers, Water soluble fertilizers, Yield parameters

HOW TO CITE THIS ARTICLE : Muthumanickam, K. and Anburani, A. (2017). Yield and yield parameters as influenced by various sources of water soluble fertilizers on chilli hybrid (Capsicum annuum L.). Asian J. Hort., 12(1) : 51-54, DOI : 10.15740/HAS/TAJH/12.1/51-54. 